\title{
FILTRATION ENRICHMENT METHOD FOR ISOLATION OF AUXOTROPHIC MUTANTS OF TRICHODERMA HARZIANUM RIFAI
}

\author{
Ana Maria R. Cassiolato ${ }^{1}$, Itamar Soares de Melo ${ }^{2 *}$ \\ ${ }^{1}$ Faculdade de Engenharia, Departamento de Biologia, Universidade Estadual Paulista, Ilha Solteira, SP, \\ Brasil. ${ }^{2}$ EMBRAPA Meio Ambiente, Jaguariúna, SP, Brasil
}

Submitted: October 09, 1996. Returned to authors for corrections: May 09, 1997; Approved: November 12, 1998

\begin{abstract}
The isolation of genetic markers, like drug resistance and auxotrophy, is a laborious but important step in genetic research. The isolation of auxotrophic mutants of Trichoderma harzianum using the filtration enrichment technique was more effective than using the total isolation technique. Most of 12 auxotrophic mutants exhibited similar growth rate and higher sporulation when compared with the wild type, but only two mutants (TWS410 and TW5-523) could grow in $500 \mu \mathrm{g} / \mathrm{L}$ of benomyl.
\end{abstract}

Key-words: Filtration enrichment technique, auxotrophic mutants, Trichoderma harzianum, benomyl

\section{INTRODUCTION}

Trichoderma spp. Rifai are the most promising producers of cellulolytic and chitinolytic enzymes, and also are currently investigated as biological control agents of plant pathogens. Their sexual state is unknown, but parasexual cycle has been studied with auxotrophic markers permitting selection of heterokaryons and of possible diploids (5). The classical method used, total isolation following mutagenic treatment, is laborious and yields a low frequency of auxotrophics among tested survivors (6). Several methods have been described for the selection of auxotrophic mutants of fungi. These include biotin-starvation methods that have been used for Aspergillus nidulans and comparable methods have been used in other fungi (6). To induce mutants of Aspergillus niger, Bos et al. (4) used low doses of the mutagen ultraviolet light (UV) in order to avoid background mutations or chromosomal rearrangements. Usually, this procedure results in high survival and low frequency of mutants among surviving prototrophics. Consequently, an efficient enrichment step can be a prerequisite. In this paper we describe the isolation of auxotrophic mutants of Trichoderma harzianum by a filtration enrichment technique based on the technique developed by Silveira and Azevedo (8) for Metarhizium anisopliae.

\section{MATERIALS AND METHODS}

Microorganism - T. harzianum TW5, originally isolated from a soybean field in Brazil, was obtained from the fungi collection of National Research Center for Monitoring and Assessment of Environmental Impact, EMBRAPA, Brazil. This strain has been shown to be antagonist to the plant pathogens Sclerotinia sclerotiorum and Sclerotinia minor.

\footnotetext{
* Corresponding author. Mailing address: EMBRAPA - Meio Ambiente, Caixa Postal 69, CEP 13820-000, Jaguariúna, SP, Brasil. Fax: (+5519) $867-8740$.
} 
Culture medium - Mineral medium (MM) and complete medium (CM) were those of Pontecorvo et al. (6), modified by Azevedo and Costa (1).

Filtration technique and isolation of auxotrophic mutants - Eight layers of stretched gauze were fixed to polypropylene filters with adhesive tape. Filters, wrapped in aluminum foil, were autoclaved at $121^{\circ} \mathrm{C}$ for 15 minutes. Conidial suspensions were prepared in aqueous Tween 80 $(0.1 \%)$, diluted and irradiated for 5 minutes with U.V. light $\left(97.72 \mu \mathrm{W} / \mathrm{cm}^{2} \times 10^{-2} / \mathrm{s}\right)$ to give $5 \%$ survival.

\section{a) Isolation of auxotrophic mutants by the conventional technique}

Treated conidia suspensions were diluted and plated on CM supplemented with sodium deoxycolate $(0.1 \%)$ and incubated for $48-72 \mathrm{~h}$ at $25^{\circ} \mathrm{C}$. Colonies were tested for growth by transfer onto $\mathrm{MM}$ and $\mathrm{CM}$ supplemented with $0.1 \%$ sodium deoxycolate, in a $5 \times 5+1$ arrangement, with a total of 26 inocula per dish (2). Colonies failing to grow were considered possible auxotrophic mutants and were tested for auxotrophy on test plates with combinations of amino acids or nucleotides or vitamin mixtures.

\section{b) Isolation of auxotrophic mutants by filtration enrichment technique}

Treated conidia were transfered to $50 \mathrm{ml}$ liquid $\mathrm{MM}$ and shaken for $20 \mathrm{~h}$ at $25^{\circ} \mathrm{C}$. After filtration, the filtrate was incubated again with agitation for additional $20 \mathrm{~h}$. The procedure was carried out three times and after the last filtration the filtrate was centrifuged at 2,900g for 15 minutes, resuspended in $3 \mathrm{ml}$ distilled water, diluted and plated on $\mathrm{CM}$ supplemented with $0,1 \%$ sodium deoxycolate $(0.1 \%)$.

Each resulting colony was inoculated on MM supplemented with $0.1 \%$ sodium deoxycolate in a $5 \times 5+1$ arrangement, with a total of 26 inocula per Petri dish (2). Colonies failing to grow were considered possible auxotrophic mutants and were tested for auxotrophy on test plates with combinations of amino acids or nucleotides or vitamin mixtures.

\section{Characterization of auxotrophy marks in the mutants}

Mutants were plated from monospore cultures and characterized for deficiency by supplementation with individual growth factors. Phenotypically similar mutants were combined in complementation tests.
Growth and sporulation of auxotrophic mutants on Potato-Dextrose-Agar (PDA) and on Oat-Agar media

Disks ( $5 \mathrm{~mm}$ in diameter) of 4-day old colonies of auxotrophic mutants of T. harzianum TW5 were transferred to the center of Petri dishes containing PDA or Oat-Agar media. The supply of amino acids or vitamins required by each auxotrophic mutant was added in appropriate quantity $(\mathrm{w} / \mathrm{v})$ to the media after autoclavation. Colony radii were measured after $72 \mathrm{~h}$. Conidia were suspended in $0.1 \%$ Tween and used to determine the conidia production after 12-days. There were three replicates per treatment, and data were expressed as percentage of growth inhibition.

\section{Growth and sporulation of auxotrophic mutants on PDA medium supplemented with benomyl}

The fungicide benomyl, methyl-1(butycarbamoyl) -2-benzimidazole carbamic acid (Benlate 50\% WP, Du Pont Co., Wilmington, DE) was suspended in acetone. The fungicide was tested at 1, 5, 10, 50, 100, 500 and $1000 \mu \mathrm{g}$ of active ingredient (a.i.) per milliliter of medium. The benomyl and the supply of amino acids or vitamins required by each auxotrophic mutant were added in appropriate quantities $(\mathrm{w} / \mathrm{v})$ to the PDA medium after autoclavation. Disks $(5 \mathrm{~mm}$ in diameter) of 4-day old colonies of auxotrophic mutants of T. harzianum TW5 were transferred to the center of Petri dishes containing the above described medium. Colony radii on solid media were measured after 6-day at $25^{\circ} \mathrm{C}$. There were three replicates per treatment and the data were expressed as percentage of growth inhibition.

\section{RESULTS AND DISCUSSION}

Using the total-isolation method, only morphological mutants were isolated (Table 1). All the auxotrophic mutants isolated were obtained by the filtration enrichment method. The results in Table 2 show the variety of amino acid-deficient mutants that were isolated. Only one vitamin-deficient mutant was found using the filtration enrichment method.

These results are in agreement with those of Bos et al. (3), with Aspergillus niger. They showed that 123 auxotrophic mutants were isolated by filtration enrichment technique, but only 9 of them were vitamin-deficient mutants. The mutants obtained in this way were predominantly amino acid requiring.

The efficiency of the total-isolation technique 
was considerably lower than that of the filtration enrichment technique for isolation of auxotrophic mutants of T. harzianum TW5. One explanation for this low efficiency is that the number of colonies tested were too small. The use of the filtration enrichment technique resulted in 11 auxotrophic mutants, in spite of having $50 \%$ less colonies than in the total-isolation technique.

Those mutants, when tested for growth speed and sporulation on PDA and Oat-Agar media, did not differ from the wild type, except by the mutants TW5-600 and TW5-53, which showed the lowest growth rates. On the other hand, these mutants exhibited higher sporulation on PDA medium (Table 3).

Table 1. Frequency of isolation of auxotrophic and morphological mutants of T. harzianum TW5.

\begin{tabular}{lcccc}
\hline \multicolumn{1}{c}{ Treatments } & $\begin{array}{c}\text { Number of } \\
\text { colonies }\end{array}$ & $\begin{array}{c}\text { Characteristics } \\
\text { of mutants }\end{array}$ & $\begin{array}{c}\text { Number } \\
\text { of mutants }\end{array}$ & $\begin{array}{c}\text { Frequency of } \\
\text { isolation (\%) }\end{array}$ \\
\hline \multirow{2}{*}{ Total isolation } & 3920 & morphologic & 29 & 0.74 \\
Filtration enrichment technique & 703 & auxotrophic & 0 & 0.00 \\
Total & & morphologic & 0 & 0.00 \\
& 4623 & auxotrophic & 11 & 1.56 \\
\end{tabular}

Table 2. Auxotrophic mutants of T. harzianum TW5, their markers, and number of tested colonies.

\begin{tabular}{lccccc}
\hline Mutants & $\begin{array}{c}\text { Auxotrophic } \\
\text { marker }\end{array}$ & $\begin{array}{c}\text { Number of } \\
\text { tested colonies }\end{array}$ & Mutants & $\begin{array}{c}\text { Auxotrophic } \\
\text { marker }\end{array}$ & $\begin{array}{c}\text { Number of } \\
\text { tested colonies }\end{array}$ \\
\hline TW5-612 & met & 93 & TW5-574 & arg & 75 \\
TW5-537 & leu & 66 & TW5-560 & arg & 93 \\
TW5-533 & leu & 57 & TW5-609 & arg & 66 \\
TW5-523 & rib, bio & 75 & TW5-534 & arg & 48 \\
TW5-600 & met, cis, arg & 66 & TW5-555 & arg & 60 \\
TW5-410 & met, cis, arg & 75 & & & \\
\hline
\end{tabular}

$\arg =\operatorname{arginin} ; \mathbf{b i o}=$ biotin $; \mathbf{c i s}=$ cistein; leu $=$ leucin; $\mathbf{m e t}=$ metionin $;$ rib $=$ riboflavin

Table 3. Mycelial growth and sporulation of auxotrophic mutants of T. harzianum TW5 on PDA and Oat-Agar media.

\begin{tabular}{lcccc}
\hline & \multicolumn{2}{c}{ Radial growth $(\mathrm{cm})$} & \multicolumn{2}{c}{ Sporulation $\left(\times 10^{6} / \mathrm{ml}\right)$} \\
Mutants & PDA medium & Oat Agar medium & PDA medium & Oat-Agar Medium \\
\hline TW5 & $8.50 \mathrm{aA}$ & $8.50 \mathrm{aA}$ & $1.637 \mathrm{bFG}$ & $4.733 \mathrm{aCD}$ \\
TW5-534 & $8.50 \mathrm{aA}$ & $8.50 \mathrm{aA}$ & $4.153 \mathrm{bDEFG}$ & $18.067 \mathrm{aAB}$ \\
TW5-555 & $8.50 \mathrm{aA}$ & $8.50 \mathrm{aA}$ & $12.200 \mathrm{bCDE}$ & $26.133 \mathrm{aAB}$ \\
TW5-560 & $8.50 \mathrm{aA}$ & $8.50 \mathrm{aA}$ & $19.933 \mathrm{bC}$ & $29.333 \mathrm{aA}$ \\
TW5-574 & $8.43 \mathrm{aA}$ & $8.50 \mathrm{aA}$ & $0.14 \mathrm{bG} 3$ & $2.233 \mathrm{aA}$ \\
TW5-612 & $8.50 \mathrm{aA}$ & $7.90 \mathrm{aAB}$ & $6.133 \mathrm{bDEF}$ & $20.200 \mathrm{aAB}$ \\
TW5-523 & $8.50 \mathrm{aA}$ & $8.50 \mathrm{aA}$ & $13.400 \mathrm{bCD}$ & $15.633 \mathrm{aAB}$ \\
TW5-609 & $7.33 \mathrm{bAB}$ & $8.50 \mathrm{aA}$ & $3.403 \mathrm{bEFG}$ & $14.300 \mathrm{aBC}$ \\
TW5-410 & $8.50 \mathrm{aA}$ & $8.50 \mathrm{aA}$ & $3.643 \mathrm{aEFG}$ & $3.340 \mathrm{bD}$ \\
TW5-533 & $8.13 \mathrm{aAB}$ & $8.50 \mathrm{aA}$ & $22.633 \mathrm{aBC}$ & $22.300 \mathrm{bAB}$ \\
TW5-600 & $5.60 \mathrm{cC}$ & $7.10 \mathrm{bBC}$ & $45.300 \mathrm{aA}$ & $15.233 \mathrm{bAB}$ \\
TW5-537 & $6.93 \mathrm{bBC}$ & $6.27 \mathrm{bC}$ & $38.000 \mathrm{aAB}$ & $20.700 \mathrm{bAB}$ \\
\hline
\end{tabular}

Means followed by different letters (capital on vertical and small on horizontal) differ significantly according to Tukey's multiple range test $(\mathrm{P} \leq 0.05)$.

Data are means of three replicates. 
According to Silveira and Azevedo (8), the filtration enrichment method is very efficient for $M$. anisopliae. These authors reported a predominance of mutants able to synthesize amino acids and nucleic acids over mutants unable to synthesize vitamins. They justified the results based on the fact that mutants with vitamin requirements may have grown as a result of vitamins released by growing prototrophs or by spontaneous cell lysis, as suggested by Strauss (9). However, the diversity of mutant types according to isolation procedure is actually valuable when a wide range of types of nutritional requirements is needed (9).

Using the methods described, benomyl resistance was obtained in two of the auxotrophic mutants (TW5410 e TW5-523). These mutants presented stable fungicide resistance and were able to grow at concentration of up to 500 and $1000 \mu \mathrm{g} / \mathrm{L}$, respectively (Table 4). We believe that these stable fungicide resistant isolates were produced as a direct result of the mutageneses treatment and are not naturally occurring spontaneous mutations.

Table 4. Mycelial growth reduction of T. harzianum TW5 mutants on PDA medium supplemented with benomyl.

\begin{tabular}{lrrrrrrrr}
\hline & \multicolumn{8}{c}{ Mycelial growth reduction } \\
\cline { 2 - 9 } Mutants & \multicolumn{8}{c}{ Concentration $(\mu \mathrm{g})$} \\
\cline { 2 - 9 } & 0 & 1 & 5 & 10 & 50 & 100 & 500 & 1000 \\
\hline TW-410 & 0 & 0 & 0 & 0 & 0 & 0 & 0 & 42 \\
TW5-523 & 0 & 0 & 0 & 0 & 42 & 62 & 61 & 61 \\
TW5-555 & 0 & 0 & 67 & 68 & 87 & 89 & 100 & 100 \\
TW5-537 & 0 & 0 & 65 & 69 & 100 & 100 & 100 & 100 \\
TW5-574 & 0 & 0 & 71 & 72 & 100 & 100 & 100 & 100 \\
TW5-534 & 0 & 0 & 76 & 78 & 100 & 100 & 100 & 100 \\
TW5-560 & 0 & 0 & 64 & 81 & 100 & 100 & 100 & 100 \\
TW5-600 & 0 & 0 & 71 & 82 & 100 & 100 & 100 & 100 \\
TW5-609 & 0 & 4 & 82 & 84 & 100 & 100 & 100 & 100 \\
TW5-612 & 0 & 32 & 69 & 100 & 100 & 100 & 100 & 100 \\
TW5-533 & 0 & 9 & 71 & 100 & 100 & 100 & 100 & 100 \\
TW5 & 0 & 55 & 100 & 100 & 100 & 100 & 100 & 100 \\
\hline
\end{tabular}

Data are means based on three replicates.

\section{RESUMO}

\section{Técnica de enriquecimento por filtração para isolamento de mutantes auxotróficos de Trichoderma harzianum Rifai}

A obtenção de marcas genéticas, quer sejam para resistência a drogas, quer para auxotrofia, é uma etapa trabalhosa mas importante em pesquisa genética. Esse trabalho visou a obtenção de mutantes auxotróficos de Trichoderma harzianum utilizando-se a técnica de enriquecimento por filtração. A técnica mostrouse superior à técnica convencional de isolamento total. Doze mutantes auxotróficos obtidos foram testados quanto a estabilidade, crescimento e resistência ao fungicida benomil. Eles apresentaram taxas de crescimento e esporulação comparáveis à linhagem parental e dois mutantes foram resistentes a benomil em uma concentração de $500 \mu \mathrm{g} / \mathrm{ml}$.

Palavras-chave: enriquecimento por filtração, mutantes auxotróficos, Trichoderma harzianum, benomil

\section{REFERENCES}

1. Azevedo, J.L.; Costa, S.O.P. Exercícios Práticos de Genética. São Paulo: EDUSP, 1973. pp. 288.

2. Azevedo, J.L.; Oliveira, A.; Rocha Cmapos, A.J. Replicador multifio para transferência de esporos de fungos filamentosos. Summa Phytopathologica, 2: 237-241, 1976.

3. Bos, C.J.; Debets, A.J.M.; Nachtegaal, H.; Slakhorst, S.M.; Swart, $\mathrm{K}$. Isolation of auxotrophic mutants of Aspergillus niger by filtration enrichment and lytic enzymes. Curr. Genet., 21: 117$120,1992$.

4. Cassiolato, A.M.R.; Baker, R.; Melo, I.S. Parasitismo de Sclerotinia sclerotiorum e S. minor por mutantes de Trichoderma harzianum, em segmentos de aipo. Fitopatol. Bras., 21: 120-122, 1996.

5. Furlaneto, M.C. Recombinação genética e produção de celulases em Trichoderma pseudokoningii var. Rifai. Piracicaba, SP, 1989, 151p. (Mestrado Escola Superior de Agricultura Luiz de Queiroz/ Universidade de São Paulo).

6. Pontecorvo, G.; Roper, J.A.; Hemmons, L.M.; McDonald, K.D.; Bufton, W.F.C The genetics of Aspergillus nidulans. Adv. Genet., 5: $141-238,1953$.

7. Silva, A.C.F. Obtenção e caracterização de novos mutantes de Trichoderma harzianum Rifai, resistentes a benzimidazóis, através da luz ultra-violeta. Piracicaba, SP., 1991. 131p. (Mestrado-Escola Superior de Agricultura Luiz de Queiroz/ Universidade de São Paulo).

8. Silveira, W.D.; Azevedo, J.L. Isolation of auxotrophic mutants of Metarhizium anisopliae by the filtration enrichment technique. Rev. Bras. Gen., 7: 1-8, 1984.

9. Strauss, B.S. Cell death and "Unbalanced growth" in Neurospora.J. Gen. Microbiol., 18: 658-659, 1958. 